\title{
Effective and humane ways to manage the drug problem in the Philippines, a human rights and public health perspective
}

\author{
Jerbert M. Briola*
}

Dear editor,

We, at the Medical Action Group (MAG), a health and human rights organization, are uniquely placed to see a particularly disturbing aspect of Duterte's drug war: it disproportionately targets the poor and vulnerable. A five-year-old girl was killed in late September 2016 after suspected gunmen aiming to kill her grandfather opened fire. A picture went viral of a wife weeping while cradling her husband, a pedicab driver and alleged drug peddler, who was shot and killed by men on motorcycles on the street of Pasay City. Filipinos immediately associated this image with Michaelango's famous Pietà sculpture. A cardboard sign next to his body carried the chilling message "Pusher ako, wag tularan" (I'm a pusher, don't do what I did). We see both the drug war's human toll and, from their story, we learn the crushing poverty of the majority of its victims.

President Rodrigo Duterte has attracted international condemnation with his violent crackdown on drugs in the Philippines. Even at its own admission, the Philippine National

^) Advocacy Officer, Medical Action Group (MAG); http://magph.org/

Police (PNP) said a total of 2,169 drug suspects have been killed in anti-drugs operations from July 12016 to January 1, 2017. These killings, which have been dressed up in the trappings of a 'war on drugs' bear all the hallmarks of punitive policies by the authorities in dealing with the drugs problem in the Philippines. This approach is contrary to the Philippines' obligations under various human rights treaties it has signed to respect the right to life and uphold due process. This was recently reiterated by UN Special Rapporteur on summary executions, Agnes Callamard: "Claims to fight illicit drug trade do not absolve the Government from its international legal obligations and do not shield State actors or others from responsibility for illegal killings." 1

Approaches premised on a punitive law enforcement paradigm have failed, emphatically so. They have resulted in more violence, larger prison populations, and the erosion of governance. The health harms associated with drug use have got worse, not better. The drug problem in the country cannot be viewed and treated simply as a law enforcement problem. Putting health and community safety first requires a fundamental reorientation of policy priorities and resources, from failed punitive enforcement to proven health and social intervention. We 
strongly advocate for an approach to drug policy that puts public health, community safety, human rights, and development at the center. We recognize the adverse effects of illegal drug use especially on youth. We are also fully aware that illegal drug use and trade have destroyed the lives and future of individuals as well as families and communities. However, while we support the government's intention to make the public safe from the harm of illegal drugs, it should not put the country in greater harm by allowing the proliferation of violence. We would particularly ask the Philippine government to take advantage of the 2016 UN General Assembly Special Session on Drugs (UNGASS), ${ }^{\mathrm{i}}$ as an opportunity to finally start fighting drug problem in public health perspective and under control.

In addition to the rise in extrajudicial killings, thousands of people have surrendered themselves to the authorities out of fear of being targeted in the drug crackdown. As of January 16,2017 , a total of $1,155,819$ drug personalities have turned themselves in, eight to ten percent of whom will need to be committed to a drug facility, according to a government report. ${ }^{\text {ii }}$ Nevertheless, an increase in arrests during Duterte's presidency has caused already overcrowded jails to further overflow with prisoners. Images from Quezon City Jail in Manila show tightly packed rows of inmates lining the floors of the facility, which was built to house 800 people but now holds 3,800 . Prisoners reportedly take turns sleeping on the ground. iii

The Global Commission on Drug Policy

\footnotetext{
${ }^{\mathrm{i}}$ http://www.unodc.org

ii http://www.dilg.gov.ph/news/New-PHP700M-drugrehabilitation-center-to-rise-in-Malaybalay/NC-2017 1055

iii http://time.com/4438112/philippines-overcrowdedprison-manila-rodrigo-duterte/
}

have stressed that a new and improved global drug control regime is needed that better protects the health and safety of individuals and communities around the world. ${ }^{2}$ Harsh measures grounded in repressive ideologies must be replaced by more humane and effective policies shaped by scientific evidence, public health principles and human rights standards.

The Global Commission on Drug Policy have also called for an end to the criminalization and incarceration of users together with targeted prevention, harm reduction and treatment strategies for dependent users. In order to reduce drug-related harms and undermine the power and profits of organized crime, the Commission recommends that governments regulate drug markets and adapt their enforcement strategies to target the most violent and disruptive criminal groups rather than punish low-level players. The Global Commission's proposals are complementary and comprehensive.

Illegal drug use happens in almost all communities and is associated with substantial health and social problems. The obstacles to reform are both daunting and diverse; the drug problem is primarily a public health issue with poverty at its root. Using the criminal justice system to force people arrested for drug possession into 'treatment' often does more harm than good; far better to ensure the availability of diverse supportive services in communities.

Rehabilitation is essential to combatting the effects of drugs. With the massive number of people who have surrendered, we cannot ignore the need for health interventions. Barriers in the provision of health services currently exist, such as the lack of treatment and rehabilitation centers nationwide due to funding problems and the fact that many services are unaffordable to the majority in need. Concerted efforts and 
evidence-based policy actions therefore need to be made. Government-run treatment facilities in the country are located only in the National Capital Region (NCR), Caraga Region and Regions I, IV-A, V, VI, VII, X and $\mathrm{XI}$. There are 42 drug rehabilitation centers nationwide which are only able to cater for 5,000 patients. Of the 42,14 are state-run while the rest are privately operated and are therefore not available to the vast majority of people in need. Community and families can definitely be helped through the establishment of community-based programs, drug after care or local support interventions for out-patients.

People's health and safety need to be at the center and the government needs to ensure access to essential medicines and pain control. This is the only way to reduce drug-related death, disease and suffering and the violence, crime, corruption and illicit markets associated with ineffective prohibitionist policies. Treatment and rehabilitation, ensuring access to essential health goods and services, education and decent employment are all necessary to eliminate this drug menace.
References:

1. United Nations Office of the High Commissioner on Human Rights 'UN experts urge the Philippines to stop unlawful killings of people suspected of drug-related offences' Available from: http://www.ohchr.org/EN/NewsEvents/Pages/ DisplayNews.aspx?NewsID=20388

2. The Global Commission on Drug Policy. Available from: http://www.globalcommissionondrugs. org

3. Statement of the Medical Action Group. Available from: http://www.magph.org/news/216address-illegal-drug-use-through-health-interventions 